\title{
ADOPTION OF MIMIC MODEL FOR ESTIMATION OF DIGITAL SHADOW ECONOMY
}

\author{
Ligita GASPARENIENE ${ }^{1}$, Rita REMEIKIENE $\dot{E}^{2 *}$, \\ Romualdas GINEVIČIUS' ${ }^{3}$, Martin SCHIEG ${ }^{4}$ \\ 1,2 Mykolas Romeris University, Ateities g. 20, LT 08303, Vilnius, Lithuania \\ ${ }^{3}$ Vilnius Gediminas Technical University, Sauletekio al. 11, LT-10223 Vilnius, Lithuania \\ ${ }^{4}$ Technical University of Munich, Arcisstr. 21, 80333 Munich, Germany
}

Received 10 February 2017; accepted 11 June 2017

\begin{abstract}
This articles analyses a contemporary problem, which has not been thoroughly analysed in scientific literature - Estimation of Digital Shadow Economy through a modified MIMIC model. It is the first pilot research of such type, which allows to reveal the need of deeper data analysis and data collection. Received results show, that three causal factors (internet access, and PC availability for households, non-cash payments, placement of innovative financial instruments on a market) and three indicators (non-cash transfers through internet payment platforms, volume of payments in cryptocurrencies and parcels, which are tax free at the customs) are not enough in order to perform interpretations of economic results. Additionally, the data set should cover longer-term data, however the limitation appears due to relatively short existence of innovative financial products and the lack of information accumulation about necessary data in statistical databases.
\end{abstract}

Keywords: digital shadow economy, MIMIC model.

JEL Classification: A12, C15, C80, E22.

\section{Introduction}

Despite much economic and scientific effort to understand the causes and effects of shadow economy, this issue remains controversial and has been extensively discussed. The results of estimations show that the scopes of shadow economy may significantly vary for different countries or regions. According to Enste (2015) "the shadow economy is hard to measure, and different methods yield different results" (p. 1). For instance, with reference to the approximate estimations, announced in the report of the global management consulting firm AT Kearney (2013), non-observed economy in Europe today is worth more than 2.1 trillion Eur, while the estimations, announced by Schneider (2015), suggest that shadow economy in Europe amounted to 18.3 percent of official GDP, i.e. nearly 2.6 trillion euros, in 2015.

\footnotetext{
*Corresponding author. E-mail: rita.remeikiene@mruni.eu
}

\section{(C) 2018 The Author(s). Published by VGTU Press}

This is an Open Access article distributed under the terms of the Creative Commons Attribution License (http://creativecommons. org/licenses/by/4.0/), which permits unrestricted use, distribution, and reproduction in any medium, provided the original author and source are credited. 
The problem of data variance while estimating the size of shadow economy may occur not only due to employment of different methodologies or consideration of different sets of determinants, but also due to underestimation or disregard of the variables and indicators of digital shadow economy. As it was noted by Holt et al. (2010), and Bossler and Holt (2012), no reliable statistics on the actual scopes of digital shadow economy have been captured either in national or international levels, which leads to unavoidable distorts in traditional estimations of the size of shadow economy.

Thus far, scientific studies on the issue of digital shadow economy have been aimed at identification of the determinants of digital shadow consumption (Neale, Fullerton 2010; Archer 2011; Zhang, Liu 2011; Taylor, 2012; Mello 2013; Camarero et al. 2014; Arli et al. 2015, etc.), the problems of cybercrime investigation (Ajala 2007; Wall, Williams 2007; Swire 2009; Bossler, Holt 2012; Ledingham, Mills 2015; Smith 2015; Brown, Gillespie 2015, etc.), and comparison of traditional and digital shadow economies (Vlachos et al. 2011; Smith 2015; Gasparèniené, Remeikienè 2015). Yet the methodologies of digital shadow economy estimation have hardly been developed, and the size of digital shadow economy has hardly been estimated. Estimation of the size of digital shadow economy, based on the methodology that would include the indicators and variables of this phenomenon, would supplement the scientific findings in the area of shadow economy, would provide a clearer understanding of the amounts of the revenue illegally earned in e-space, and could contribute to purposeful development of the measures aimed at investigation and prevention of digital shadow economy.

The purpose of this article is to estimate the size of digital shadow economy by employing a specially-prepared methodology, which is based on the variables and indicators of the researched phenomenon. To our knowledge, this type of scientific research has been conducted for the first time. For the fulfilment of the defined aim, the following objectives have been raised: 1) to review the variables and indicators of digital shadow economy; 2) to develop and introduce the methodology of the research; 3) based on the specially-prepared methodology, to estimate the size of digital shadow economy in Lithuania during 2014 I quarter until 2016 III quarter. The methods of the research include systematic and comparative analysis of the scientific literature, adjustment of the MIMIC (further Multiple Indicators Multiple Causes) model.

\section{Proposed causal variables and indicators of digital shadow economy: theoretical background}

The researchers who attempt to estimate the size of shadow economy face a complicated task to evaluate the impact of various determinants on this phenomenon. With reference to the Regulation No. 549/2013 of the European Parliament and of the Council (2013) on the European system of national and regional accounts in the European Union, there is no obligation for the member-states to measure the size of non-observed economy in the European system of national accounts. On the other hand, the states are obliged to ensure the exhaustiveness of estimated GDP and GNI. For this reason, the size of non-official economy is included in the estimations of GDP (Juškienè 2015; Eurostat 2016). The institutions au- 
thorised to make and report the above-mentioned estimations (e.g. departments of statistics in the EU member-states) are free to select the methodologies, which may include a variety of variables and indicators.

In order to identify the proposed causal variables and indicators of digital shadow economy, the concept of digital shadow economy must be presented. According to Remeikiene et al. (2018) "digital shadow economy represents illegal activities, which have to be separated from criminal actions, although both types of activities are performed violating existent legal norms and regulations. Digital shadow businesses are executed by exceptionally exploiting the Internet and e-space as the platforms for service provision or sales. While operating in digital environment, a pursuit for profit as well as voluntary participation emerge as the key criteria of digital shadow business, causing the damage to the state in the form of unaccounted, undeclared revenues and unpaid taxes" (p. 12).

The results of the expert evaluation on plausible causal variables and indicators of digital shadow economy in Lithuania (the results of the evaluation have not still been published or publically announced) revealed that an approximate size of digital shadow economy can be estimated by employing such causal variables as household access to the Internet and IT, non-cash payments, and introduction of financial innovations, while main indicators of the researched phenomenon cover the volumes of payments in cryptocurrencies (e.g. Bitcoins), non-cash transfers via online payment platforms, and monetary value of the parcels for which no custom duties are paid.

Household access to the Internet and IT is considered as one of the causal variables of digital shadow economy since having an access to advanced technologies, households provide themselves with the necessary technical equipment to operate in digital space. In other words, the Internet and IT are referred to as structural parts of the technical environment of digital shadow economy (Ingram, Hinduja 2008; Amasiatu, Shah 2014; Camarero et al. 2014). The significance of IT in daily operations of households is confirmed by the statistical data of the last few years. For instance, following the report of the Information Society Development Committee under the Ministry of Transport and Communications (2015), over the first quarter of 2014, 66 percent of Lithuanian people had personal computers and the Internet access at home. Over the first quarter of 2015, this number increased by 2 percentage points, and over the first quarter of 2016 - by 4 percentage points (Lithuanian Department of Statistics 2016). Nearly all Lithuanian households (i.e. 99 percent of the total number of households) with the Internet access use broadband Internet (Information Society Development... 2015). Three quarters (i.e. 67 percent) of Lithuanian households without Internet access note that they do not need an Internet access at home because they can freely use it at work or in other public places (e.g. libraries) (Lithuanian Department of Statistics 2016).

While analysing the differences between traditional and digital shadow economies, Gasparenienè and Remeikienè (2015) found that both economies share one distinctive feature: in both traditional and digital shadow economies payments are performed not only in cash. Although non-cash payments (e.g. credit transfers, direct online debits, payments in debit cards, e-money, e-transfers, etc.) are promoted by central banks with the aim to reduce the size of shadow economy (i.e. it is considered that e-transfers made by employing online banking systems can easier be tracked by state tax inspectorates and other authorised 
institutions) (The Bank of Lithuania 2016), it is also the case that settlements for unreported digital operations are made only by employing remote methods of payment (e.g. e-transfers, e-money, cryptocurrencies, etc.) (Brown, Gillespie 2015). Hence, the volumes of non-cash payments can be considered as one of the causal variables of digital shadow economy.

Leading positions in Lithuanian market of electronic payments are occupied by commercial banks, though the latter are facing the increased competition from the side of electronic money institutions, i.e. former institutions of traditional payment that transferred their operations to digital space (The Bank of Lithuania 2016). As it can be judged by their name, electronic money institutions focus on issuance and redemption of electronic money, and performance of payments in electronic money. With reference to the report of the Bank of Lithuania (2016), in 2015, the share of payments in electronic money significantly increased in Lithuanian payment market: over the first quarter of 2015, it composed nearly 30 percent of the total number of payments, while over the second quarter of 2015, it jumped to 63 percent. The payments inside an institution or settlements with other electronic payment institutions composed nearly 48 percent of the total number of operations in electronic payment institutions in Lithuania; local credit transfers amounted to nearly 38 percent of the total number of operations; money transfers to foreign countries composed nearly 14 percent of the total number of operations (The Bank of Lithuania 2016).

Finally, digital shadow economy is considered to be caused by introduction of innovative financial instruments. International finance markets have started to accept payment cards (e.g. Revolut), which allow to cash money for free. Revolut is a global money app, which covers a debit card (Mastercard), currency exchange, and peer-to-peer payments (Dillet 2015). It was launched to the public in July 2015 with the aim of building a fair and frictionless platform to use and manage money around the world by removing hidden fees and offering interbank currency rates (Revolut Limited 2015). Revolut currently charges no fees for the majority of its services, and claims to use interbank rates for its currency exchange (except from week-end rates when markets are closed, where a $0.5 \%$ markup is added to the Friday rate) (Hawkins 2016). The London-based startup currently supports spending and ATM withdrawals in 90 currencies and sending in 23 currencies directly from the mobile app (Revolut Limited 2015). The main advantage of such cards is that they are issued without cost: as of December 2016, "Revolut" is available to legal residents of EU and some of its members' dependency territories. What is more, the cards assure a comparatively high level of safety. Nevertheless, the factors of convenience and anonymity often make this online settlement system a favourable environment for transfers of "dirty money". For instance, Revolut consumers have to confirm their identities only in case contributions to their accounts exceed 1000 Eur (Revolut Limited 2015). Therefore, employment of financial innovations, such as Revolut, is a perfect opportunity to make transactions related to reception of non-taxable income.

After the review of proposed causal variables of digital shadow economy, it is purposeful to analyse the proposed indicators of this phenomenon. As it was mentioned above, proposed indicators of digital shadow economy cover the volumes of payments in cryptocurrencies (e.g. Bitcoins), non-cash transfers via online payment platforms, and monetary value of the parcels for which no custom duties are paid. 
By their purpose, cryptocurrencies can be considered as a type of electronic money and an innovative measure of settlements that allows to make fast payments for products or services acquired online. Over the last few years, Bitcoin has become the most widely used cryptocurrency, which ensures anonymous and extremely fast payments with lower money transfer costs in comparison to those generated while using traditional bank cards. Since usage of Bitcoins is not regulated either by Lithuanian laws or the EU directives, customers are the subjects that bear all the responsibility for Bitcoin usage (Galdikienè 2013; Ciaian et al. 2014). Nevertheless, despite convenience of usage, Bitcoins cause particular risks for national and international economies because the majority of the states hardly regulate this area of finance (with the exception of Germany and Switzerland that are treated as the states most advanced in the area of Bitcoin usage regulation), do not charge direct or indirect taxes for transactions, do not oblige the subjects to estimate and report their revenue or profits, etc. This way, Bitcoins are becoming an increasingly appealing method of settlements while making unreported transactions online, i.e. while performing transactions in digital shadow economy. Hence, consideration of the frequency of payments in cryptocurrencies, such as Bitcoins, may serve as one of the indicators of the scopes of digital shadow economy.

Technological progress has determined appearance of the methods of international settlements, more modern than ordinary bank transfers. Indeed, introduction of online payment platforms (e.g. Payza, Paysera, PayPal, Transfergo, Opal, Moneygram, etc.) has revolutionised the system of international transfers. The above-mentioned online payment platforms, developed for personal customers and businesses, are available 24 hours a day with competitive rates and fees. They allow to buy and sell different currencies, use debit cards or funds already on account with the platform, store payment and recipient details to make repeat transfers or pay by bank transfers to add cleared funds to one's account (Federal Deposit Insurance Corporation 2014). As of 2015, there were over 192 million active Paypal accounts in more than 200 markets, allowing customers to get paid in more than 100 currencies, withdraw funds to their bank accounts in 56 currencies, and hold balances in their accounts in 25 currencies (Paypal 2016). With reference to non-official statistics (Digital finance information website IBAN.lt, 2016), from June to December 2015, 10.46 percent of Lithuanian consumers chose payments by Paypal; the share of contributions collected by Paypal amounted to 11.53 percent. From January to October 2016, payments by Paypal were chosen by nearly 12.2 percent of Lithuanian consumers, and the share of contributions collected by Paypal exceeded 15.62 percent. Online wallets (or digital wallets) (e.g. Skrill (Moneybookers), Neteller, etc.) are increasingly being employed while paying for online purchases without usage of a bank card or making a bank transfer. They refer to a program or a web service that provides a quick method for consumers to purchase products from any person or shop across the world (Federal Deposit Insurance Corporation 2014). Online wallets are convenient for customers who avoid disclosing their bank data or identity information. Following the information in Lithuanian international transfer advisory website Pinigu pervedimai.lt (2013), due to assurance of anonymity, online payment platforms and digital wallets are often used for settlements in poker, betting or e-game sites. Hence, they are an attractive measure of payments for digital shadow operations. 
When customers buy a product or service from a foreign country (for citizens of the EU - from a non-EU country), then they are treated as importers and become liable to customs, excise duty and VAT payments (European Commission 2016). If the terms of sale do not specify any other arrangement, the products being imported would normally be held by the Customs Authority at entry in a host country, and the payment of duty and tax will be charged. Nevertheless, since customs, excise duties and VAT are likely to be paid on the top of the advertised purchase price, customers often want to hide the real value of their purchases. Some commercial websites may even offer to show a value on the Customs Declaration that is much lower than the actual price of the purchase. This way, the real value of goods and money flows remains unreported. Detection of the cases of this type of fraud results in punishment of the contract parties and seizure of the goods. For this reason, the monetary value of the seized parcels for which no custom duties are paid may serve as one of the indicators of digital shadow economy.

Summarising, presuming that performance of digital shadow activities requires special environment, which covers availability of IT and the Internet, non-cash payment methods and financial innovations, it can be proposed that causal variables of the size of digital shadow economy include household access to the Internet and IT, volumes of non-cash payments, and volumes of the usage of financial innovations. The main indicators of the size of digital shadow economy include frequency of payments in cryptocurrencies (e.g. Bitcoins), noncash transfers via online payment platforms, and monetary value of the seized parcels for which no custom duties are paid.

\section{The methodology of the research}

In spite of some criticism (Elgin, Schneider 2013; Schneider et al. 2015; Juškienè 2015), MIMIC latent variable model is considered the most comprehensive methodology of shadow economy estimation. Hence, we can adjust it to estimation of the multitude of digital shadow economy. Digital shadow economy is considered as a latent variable, which, on one side, is related to the set of observed indicators (this way, the changes in the multitude of digital shadow economy are revealed), and on the other side - to the set of causal variables, which have a considerable impact on the multitude of the researched phenomenon.

MIMIC latent variable model is considered the most comprehensive methodology of shadow economy estimation. Hence, we can adjust it to estimation of the multitude of digital shadow economy. Digital shadow economy is considered as a latent variable, which, on one side, is related to the set of observed indicators (this way, the changes in the multitude of digital shadow economy are revealed), and on the other side - to the set of causal variables, which have a considerable impact on the multitude of the researched phenomenon. When a sufficient quantity of indicative and causal data is available, the model is developed by employing pretty standard procedures of econometrics.

Digital shadow economy $(\dot{\eta})$ is a scalar variable, which is linearly described by a set of directly observed variables $\mathrm{X}_{1}, \mathrm{X}_{2}, \ldots, \mathrm{X}_{\mathrm{q}}$ and scalar random noise $(\zeta)$.

$$
\dot{\eta}=\mathrm{Y}_{1} \mathrm{X}_{1}+\mathrm{Y}_{2} \mathrm{X}_{2}+\ldots+\mathrm{Y}_{\mathrm{q}} \mathrm{X}_{\mathrm{q}}+\zeta
$$


Latent (hidden) variable ( $\dot{\eta})$, in turn, directly describes endogenous variables $\mathrm{Y}_{1}, \zeta \mathrm{Y}_{2}, \ldots$, $\mathrm{Y}_{\mathrm{p}}$, which are dependent on the levels of scalar noise $\varepsilon_{1}, \varepsilon_{2}, \ldots, \varepsilon_{\mathrm{p}}$ :

$$
\begin{aligned}
y_{1}= & \lambda_{1} \dot{\eta}+\varepsilon_{1} \\
y_{2}= & \lambda_{2} \dot{\eta}+\varepsilon_{2} ; \\
& (\ldots) \\
y_{\mathrm{p}}= & \lambda_{\mathrm{p}} \dot{\eta}+\varepsilon_{\mathrm{p}} .
\end{aligned}
$$

Structural noise $(\zeta)$ and estimation errors $\varepsilon$ have a normal distribution and are linearly independent. Then, the following marking is introduced:

$\mathrm{X}^{\mathrm{T}}=\left(\mathrm{x}_{1}, \mathrm{x}_{2}, \ldots, \mathrm{x}_{\mathrm{q}}\right)$ - observed exogenous variables (causes);

$\mathrm{Y}^{\mathrm{T}}=\left(\mathrm{Y}_{1}, \mathrm{Y}_{2}, \ldots, \mathrm{Y}_{\mathrm{q}}\right)$ - structural parameters (structural model);

$\mathrm{y}^{\mathrm{T}}=\left(\mathrm{y}_{1}, \mathrm{y}_{2}, \ldots, \mathrm{y}_{\mathrm{q}}\right)-$ observed endogenous variables (indicators);

$\lambda^{\mathrm{T}}=\left(\lambda_{1}, \lambda_{2}, \ldots, \lambda_{\mathrm{q}}\right)$ - structural parameters (estimation model);

$\varepsilon^{\mathrm{T}}=\left(\varepsilon_{1}, \varepsilon_{2}, \ldots, \varepsilon_{\mathrm{q}}\right)$ - estimation errors;

$\mathrm{v}^{\mathrm{T}}=\left(\mathrm{v}_{1}, \mathrm{v}_{2}, \ldots, \mathrm{v}_{\mathrm{q}}\right)$ - standard deviation of estimation errors.

Formulas (1) and (2) can be rewritten as:

$$
\dot{\eta}_{\mathrm{t}}=\mathrm{Y}^{\mathrm{T}} \mathrm{x}_{\mathrm{t}}+\zeta_{\mathrm{t}}
$$

and

$$
\mathrm{y}_{\mathrm{t}}=\lambda \dot{\eta}_{\mathrm{t}}+\varepsilon_{\mathrm{t}}
$$

It is presumed that $\mathrm{E}\left(\zeta \varepsilon^{\mathrm{T}}\right)=0, \mathrm{E}\left(\zeta^{2}\right)=\sigma^{2}$, and $\mathrm{E}\left(\varepsilon \varepsilon^{\mathrm{T}}\right)=\Theta^{2}$.

$\Theta_{\text {pxp }}$ refers to a diagonal matrix with $\mathrm{v}$, which is located in its diagonal.

The model can be converged into a reduced form, i.e. a function of observed variables:

$$
\mathrm{y}=\lambda\left(\mathrm{Y}^{\mathrm{T}} \mathrm{x}+\zeta\right)+\varepsilon=\Pi \mathrm{x}+\mathrm{v} .
$$

Here $\Pi=\lambda \mathrm{Y}^{\mathrm{T}}$, and $\mathrm{v}=\lambda \zeta+\varepsilon$.

This way, the matrix of model covariation is developed:

$$
\Sigma=\left(\lambda\left(\mathrm{Y}^{\mathrm{T}} \Phi \mathrm{Y}+\Psi\right) / \Phi Y \lambda^{\mathrm{T}}+\Theta \varepsilon \lambda \mathrm{Y}^{\mathrm{T}} \Phi / \Phi .\right.
$$

Latent (hidden) variable ( $\dot{\eta})$ is invisible, and its value remains unknown. The other parameters of the model have to be evaluated by analysing the links between the observed variables in the dispersion and covariation. The main aim is to find the values of parameters $\mathrm{Y}$ and $\lambda$, and the estimate $\Sigma$.

Interaction between causal variables $\mathrm{X}_{\mathrm{q}}$, multitude of shadow economy (i.e. latent variable $\eta$ ), and indicative $(\eta)$ variables $Y_{p}$ over a particular period has been depicted in Figure 1 .

In this research, the structural model is related to latent variable $\eta$ (the index of shadow economy) and its causal determinants $\mathrm{X}_{\mathrm{q}}\left(\mathrm{X}_{1}\right.$ - access to the Internet and a computer in households; $\mathrm{X}_{2}$ - non-cash payments; $\mathrm{X}_{3}$ - introduction of innovative market instruments (e.g. "Revolut" card). Considering a random variable $\zeta$, it can be expressed as:

$$
\eta \dot{\eta}=Y_{1} X_{1}+Y_{2} X_{2}+Y_{3} X_{3}+\zeta \text {. }
$$


On the other hand, the estimation model links latent variable $\eta$ with its indicators $\left(\mathrm{Y}_{1}-\right.$ non-cash money transfers via online platforms; $\mathrm{Y}_{2}$ - frequency and amounts of payments in cryptographic currencies; $\mathrm{Y}_{3}$ - parcels for which no taxes (or custom duties) are paid (i.e. non-cash settlements are made)) by considering random errors $\varepsilon$ :

$$
\begin{aligned}
& \mathrm{y}_{1}=\lambda_{1} \dot{\eta}+\varepsilon_{1} ; \\
& \mathrm{y}_{2}=\lambda_{2} \dot{\eta}+\varepsilon_{2} ; \\
& \mathrm{y}_{3}=\lambda_{3} \dot{\eta}+\varepsilon_{3} .
\end{aligned}
$$

By incorporating the above-described variables, we can develop an exemplary MIMIC 3-1-3 model (see Figure 2).

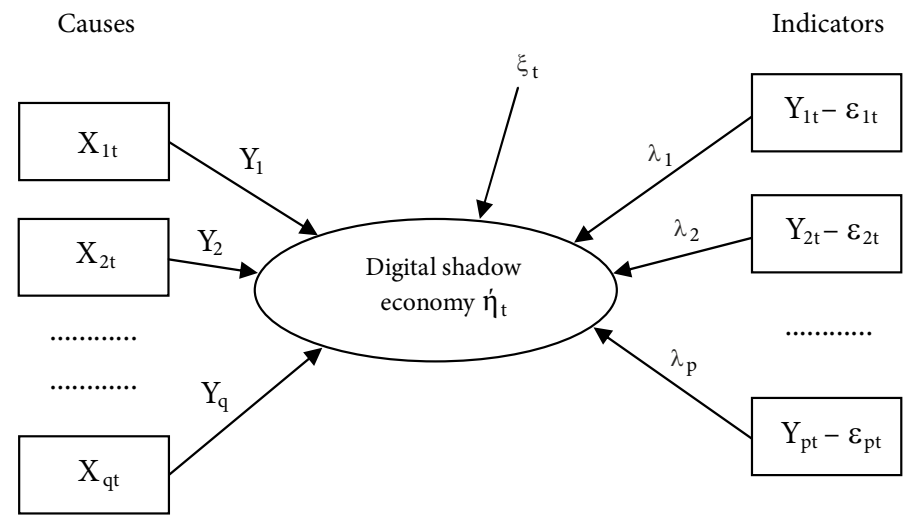

Figure 1. General structure of the MIMIC model

$$
\text { Causes } \mathrm{X}_{\mathrm{t}}\left(\mathrm{X}_{1}, \mathrm{X}_{2}, \mathrm{X}_{3}\right) \quad \text { Indicators } \mathrm{Y}_{\mathrm{t}}\left(\mathrm{Y}_{1}, \mathrm{Y}_{2}, \mathrm{Y}_{3}\right)
$$

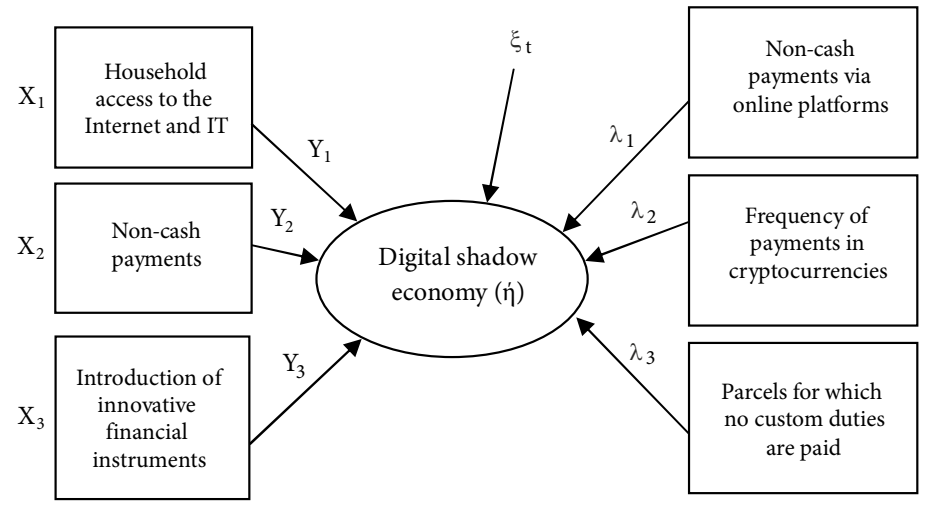

Figure 2. General structure of MIMIC 3-1-3 for estimation of the size of digital shadow economy.

Numbers 3-1-3 mark that 3 causal variables, and 3 indicators are included in the model 


\section{Calculation of Digital Shadow Economy Level: pilot research}

In order to start creating the model of Digital Shadow Economy, first of all, it was determined, whether the data satisfies the requirements for modified MIMIC model:

1. Observed variables should be dispersed normally. This requirement is often ignored in practical applications, it is only required, that those variables should be in intervals with a condition, that the amount of data is not small. If we want to apply methods, for example ADF (Asymptotically Distribution Free) in order to normalise data, then sufficient data amount should be $>100$. Ignoring this criterion and applying standard research methods, distorted parameter estimates and unreliable statistical conclusions are received.

2. Outliers should not be present in data. If there are any very outlying observations, standard model parameter estimation methods are not suitable. Outliers were identified in non-cash operation value of a thousand EUR variable.

3. Data should be enough to assess. The most common used samples consist of 150 to 500 observations. Data number could be related to the number of assessed parameters and should be 10-20 times bigger than the assessed parameter. Which means, that if 5 parameters are now included into the model, the number of data should be at least $50-100$.

4. Multicollinearity of observed variables should not be present. The meaning of correlation coefficient between variables should not be close to one. Multicollinearity of variables could mispresent their dependencies, which means that a contrary sign of a multiplier could appear in a model, then it should be. Correlation coefficient between indicator variables in analysed data: internet access and households, possessing personal computer, and the value of non-cash operations is equal to 0.95 , which means that variables are strongly dependent on each other and their meaning of correlation coefficient is close to one.

In order to assess the level of Digital Shadow Economy in Lithuania, we have managed to collect 11 meanings from indicated factors in Figure 2, from the $1^{\text {st }}$ quarter of 2014 until the $3^{\text {rd }}$ quarter of 2016 . The number of operations, performed online, is increasing, this tendency is observed globally (see Figure 3).

As a result, an assumption can be made, that the growth of criminal activity is noticed, which is transferred to digital world, since many new financial innovations have been created (for example, cryptocurrency, payment cards "Revolut" and other), which guarantee anonymity, low possibility of detection and wide geographical coverage.

During the pilot research, the goal was to gather as much as possible statistical information about the factors, named in Figure 2. The following limitations were faced during the pilot research:

- Placement of innovative financial instruments on a market (chosen payment card "Revolut") had lack of data availability. British Start-up card "Revolut" entered Lithuanian payments market only on August, in 2016, however, the information about payments with this card is available only within the frames of global statistics, without country classification or region classification; 

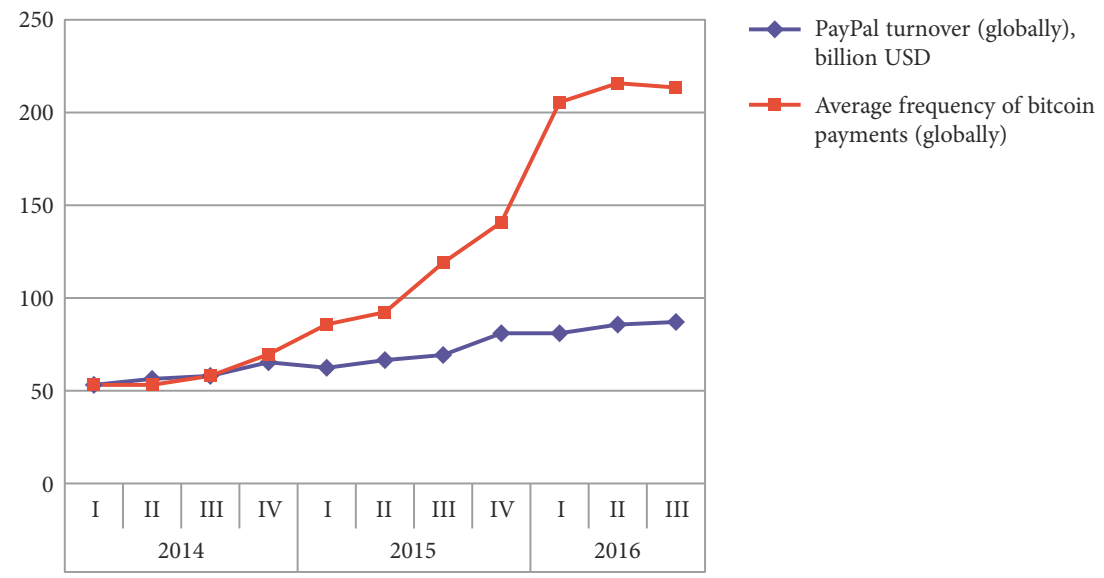

Figure 3. PayPal turnover (globally), billion USD and average frequency of bitcoin payments (globally), times a day, dynamics during 2014-2016 (Source: compiled by the authors with the reference to data from Statista)

- PayPal turnover and payment volume in bitcoin - data rows could cover information from 2008, however, this information is also global. There is no possibility to get specific information for a country;

- Parcels, taxes for which are not paid, were not included into the initial calculations of the model, because per existing legal directives, Lithuanian Customs do not gather information about monetary value of received parcels.

In order to calculate the amount of Digital Shadow Economy in a specific region, reliable statistical data for a specific region/country is necessary. The features of Digital Shadow Economy are anonymity of performed transactions, unknown geographical location between the contract parties, which allow stating, that the statistics of couple of causal factors and indicators could be global statistics, however, the remaining variables should reflect analysed country specifics, as non-cash payments (official statistics is announced by the central banks), also internet access and possession of personal computers among households (official statistics is announced by the departments of statistics). It is recommended to include bigger number of causal factors and indicators in further researches, which cover the specifics of "digital shadow" in a particular country.

Summarising the primary results of empirical research, a conclusion can be made, that provided data did not satisfy all acceptable assumptions for the model due to the lack of data and too low number of indicator choice.

\section{Conclusions}

The assessment of Digital Shadow Economy Level has not been performed neither in scientific literature nor in any other type of literature. Based on one of existing Shadow Economy Level assessment methods (MIMIC), applying other variables, the new model for the assessment of Digital Shadow Economy has been created, including such causal factors as internet 
access and possession of personal computer among households, non-cash payments, the entrance of innovative financial instruments on a market, and covering such indicators as non-cash money transfers through internet payment platforms, payment volume in cryptocurrencies and parcels, for which taxes are not paid in customs.

During the pilot research (Lithuania, timeframe during $1^{\text {st }}$ quarter, 2014-3 $3^{\text {rd }}$ quarter, 2016) has been identified, that there is a lack of statistical data in order to assess Digital Shadow Economy Level, of such causal factors, as the entrance of innovative financial instruments on a market, due to their novelty, and the indicator, which covers the parcels, for which taxes are not paid in customs, and data is not gathered about them according to existing EU legal directives. For other variables (non-cash transfers through internet platforms, payment volume in cryptocurrencies) the statistics available is only global, but not for a particular country or region.

In order to be more precise during the second attempt to assess Digital Shadow Economy Level of a respective country, it is necessary to develop researches in this area including more indicators into MIMIC model and try look for the possibilities to receive longer dynamic row of necessary data.

\section{Acknowledgements}

This work was supported by the Research Council of Lithuania [grant number MIP-15642].

\section{References}

Ajala, E. B. 2007. Cybercafes, cybercrime detection and prevention, Library Hi Tech News 24(7): 26-29. https://doi.org/10.1108/07419050710824705

Amasiatu, C. V.; Shah, M. H. 2014. First party fraud: a review of the forms and motives of fraudulent consumer behaviours in e-tailing, International Journal of Retail \& Distribution Management 42(9): 805-817. https://doi.org/10.1108/IJRDM-05-2013-0112

Archer, N. 2011. Consumer identity theft prevention and identity fraud detection behaviours, Journal of Financial Crime 19(1): 20-36. https://doi.org/10.1108/13590791211190704

Arli, D.; Tjiptono, F.; Porto, R. 2015. The impact of moral equity, relativism and attitude on individuals' digital piracy behaviour in a developing country, Marketing Intelligence \& Planning 33(3): 348-365. https://doi.org/10.1108/MIP-09-2013-0149

AT Kearney. 2013. The shadow economy in Europe 2013 [online], [cited 16 November 2016]. Financial Institutions. Available from Internet: https://www.atkearney.com/financial-institutions/featuredarticle/-/asset_publisher/j8IucAqMqEhB/content/the-shadow-economy-in-europe-2013/10192

Bossler, A. M.; Holt, T. H. 2012. Patrol officers' perceived role in responding to cybercrime, Policing: An International Journal of Police Strategies \& Management 35(1): 165-181. https://doi.org/10.1108/13639511211215504

Brown, R.; Gillespie, S. 2015. Overseas financial investigation of organised crime: examining the barriers to effective implementation, Journal of Money Laundering Control 18(3): 371-381. https://doi.org/10.1108/JMLC-03-2014-0010

Camarero, C.; Anton, C.; Rodriguez, J. 2014. Technological and ethical antecedents of e-book piracy and price acceptance: evidence from the Spanish case, The Electronic Library 32(4): 542-566. https://doi.org/10.1108/EL-11-2012-0149 
Ciaian, P.; Rajcaniova, M.; d'Artis, K. 2014. The economics of Bitcoin price formation [online], [cited 16 November 2016]. Available from Internet: https://arxiv.org/ftp/arxiv/papers/1405/1405.4498.pdf

Digital finance information website IBAN.lt. 2016. Mokejimu priemonès [Payment measures] [online], [cited 28 December 2016]. Available from Internet: http://iban.lt/category/mokejimu-priemones/ (in Lithuanian)

Dillet, R. 2015. Revolut raises $\$ 2.3$ million for its mobile foreign exchange service [online], [cited 14 November 2016]. Available from Internet: https://techcrunch.com/2015/07/20/revolut-raises-2-3-million-for-its-mobile-foreign-exchange-service/

Elgin, C.; Schneider, F. 2013. Shadow economies in OECD countries: DGE vs MIMIC approaches [online], [cited 15 December 2016]. Available from Internet: http://www.econ.boun.edu.tr/content/ wp/EC2013_13.pdf

Enste, D. H. 2015. The shadow economy in industrial countries [online], [cited 28 December 2016]. Available from Internet: http://wol.iza.org/articles/shadow-economy-in-industrial-countries.pdf

European Commission. 2016. Buying goods online coming from a non-European Union country [online], [cited 28 December 2016]. Available from Internet: http://ec.europa.eu/taxation_customs/individuals/buying-goods-services-online-personal-use/buying-goods/buying-goods-online-coming-froma-noneu-union-country_en

European Parliament and the Council. 2013. Regulation No. 549/2013 on the European system of national and regional accounts in the European Union, Official Journal of the European Union 174 [online], [cited 28 December 2016]. Available from Internet: http://eur-lex.europa.eu/legal-content/ $\mathrm{EN} / \mathrm{TXT} / \mathrm{PDF} /$ ?uri=uriserv:OJ.L_.2013.174.01.0001.01.ENG

Eurostat. 2016. Building the system of national accounts - non-observed sector [online], [cited 15 December 2016]. Available from Internet: http://ec.europa.eu/eurostat/statistics-explained/index.php/ Building_the_System_of_National_Accounts_-_non-observed_sector

Federal Deposit Insurance Corporation. 2014. Safe Internet banking [online], [cited 28 December 2016]. Available from Internet: https://www.fdic.gov/bank/individual/online/safe.html

Galdikienè, L. 2013. Bitkoinai - ateities valiuta ar vienadienè žvaigždè? [Bitcoins - a future currency or an instant star?] [online], [cited 15 December 2016]. Available from Internet: http://www.delfi. lt/verslas/verslas/l-galdikiene-bitkoinai-ateities-valiuta-ar-tik-vienadiene-zvaigzde.d?id=63544394 (in Lithuanian)

Gaspareniene, L.; Remeikienė, R. 2015. Digital shadow economy: a critical review of literature, Mediterranean Journal of Social Sciences 6(6S5): 402-409.

Hawkins, C. 2016. Revolut: not necessarily cheaper than an(y) other Mastercard [online], [cited 28 December 2016]. Available from Internet: https://metabubble.net/payment-cards-bank-accounts/ revolut-not-necessarily-cheaper-than-any-other-mastercard/\#Fixed_weekend_exchange_rate

Holt, T. J.; Blevins, K. R.; Burkert, N. 2010. Considering the paedophile subculture on-line, Sexual Abuse: Journal of Research and Treatment 22(1): 3-24. https://doi.org/10.1177/1079063209344979

Information Society Development Committee under the Ministry of Transport and Communications. 2015. Kompiuterius ir interneto prieiga namuose turejo 66 procentai namu ükiu [Computer and Internet access was available to 66 percent of households] [online], [cited 18 December 2016]. Available from Internet: http://ivpk.lrv.lt/lt/naujienos/kompiuterius-ir-interneto-prieiga-namuoseturejo-66-procentai-namu-ukiu (in Lithuanian)

Ingram, J.; Hinduja, S. 2008. Neutralizing music piracy: an empirical examination, Deviant Behaviour 29(4): 334-366. https://doi.org/10.1080/01639620701588131

Juškienè, G. 2015. Overview of the methods used to ensure exhaustiveness the national accounts of Lithuania [online], [cited 15 November 2016]. Available from Internet: http://www.oecd.org/std/ na/2069700.pdf

Ledingham, R.; Mills, R. 2015. A preliminary study of autism and cybercrime in the context of international law enforcement, Advances in Autism 1(1): 2-11. https://doi.org/10.1108/AIA-05-2015-0003 
Lithuanian Department of Statistics. 2016. Informaciniu technologijų naudojimas namu ükiuose [Usage of information technologies in households] [online], [cited 18 December 2016]. Available from Internet: https://osp.stat.gov.lt/informaciniai-pranesimai?eventId=62513 (in Lithuanian)

Lithuanian international transfer advisory website Pinigu pervedimai.lt. 2013. Tarptautiniu pinigu perlaidu bendroviu palyginimas [Comparison of international money transfer companies] [online], [cited 28 December 2016]. Available from Internet: http://www.pinigupervedimai.lt/tarptautiniupinigu-perlaidu-bendroviu-palyginimas/ (in Lithuanian)

Mello, J. P. 2013. Cybercrime fuelled by mature digital underground [online], [cited 10 November 2016]. Available from Internet: http://www.csoonline.com/article/2133649/identity-access/cybercrimefueled-by-mature-digital-underground.html

Neale, L.; Fullerton, S. 2010. The international search for ethics norms: which consumer behaviors do consumers consider (un)acceptable?, Journal of Services Marketing 24(6): 476-486. https://doi.org/10.1108/08876041011072591

Paypal. 2016. Who we are [online], [cited 28 December 2016]. Available from Internet: https://www. paypal.com/us/webapps/mpp/about

Remeikiene, R.; Gaspareniene, L.; Schneider, F. G. 2018. The definition of digital shadow economy, Technological and Economic Development of Economy 24(2): 696-717. https://doi.org/10.3846/20294913.2016.1266530

Revolut Limited. 2015. Simply revolutionary [online], [cited 14 December 2016]. Available from Internet: https://revolut.com/about

Schneider, F. 2015. Size and development of the shadow economy of 31 European and 5 other OECD countries from 2003 to 2015: different developments [online], [cited 18 December 2016]. Available from Internet: http://www.econ.jku.at/members/schneider/files/publications/2015/shadeceurope31.pdf

Schneider, F.; Raczkowski, K.; Mróz, B. 2015. Shadow economy and tax evasion in the EU, Journal of Money Laundering Control 18(1): 34-51. https://doi.org/10.1108/JMLC-09-2014-0027

Smith, G. S. 2015. Management models for international cybercrime, Journal of Financial Crime 22(1): 104-125. https://doi.org/10.1108/JFC-09-2013-0051

Statista. 2017a. Bitcoin price index from November 2014 to November 2016 (in U.S. dollars) [online], [cited 18 December 2016]. Available from Internet: https://www.statista.com/statistics/326707/ bitcoin-price-index/

Statista. 2017b. PayPal's total payment volume from 1st quarter 2014 to 4th quarter 2016 (in billion U.S. dollars) [online], [cited 18 December 2016]. Available from Internet: https://www.statista.com/statistics/277841/paypals-total-payment-volume/

Swire, P. 2009. No cop on the beat: underenforcement in e-commerce and cybercrime, Journal of Telecommunications and High Technology Law 7(1): 107-126.

Taylor, S. A. 2012. Evaluating digital piracy intentions on behaviours, Journal of Services Marketing 26(7): 472-483. https://doi.org/10.1108/08876041211266404

The Bank of Lithuania. 2016. Mokejimai negrynaisiais pinigais [Non-cash payments] [online], [cited 28 December 2016]. Available from Internet: https://www.lb.lt/mokejimai_negrynaisiais_pinigais (in Lithuanian)

Vlachos, V.; Minou, M.; Assimakopouos, V.; Toska, A. 2011. The landscape of cybercrime in Greece, Information Management \& Computer Security 19(2): 113-123. https://doi.org/10.1108/09685221111143051

Wall, D. S.; Williams, M. 2007. Policing diversity in the digital age: maintaining order in virtual communities, Criminology and Criminal Justice 7(4): 391-415. https://doi.org/10.1177/1748895807082064

Zhang, G.; Liu, Z. 2011. Effects of influential factors on consumer perceptions of uncertainty for online shopping, Nankai Business Review International 2(2): 158-171. 